\title{
Efficient Production of loxP Knock-in Mouse using CRISPR/Cas9 System
}

\author{
Sundo Jung ${ }^{\dagger ; *}$ \\ Department of Biomedical Laboratory Science, Shinhan University, Gyeonggi-do 11644, Korea
}

Of the various types of mice used for genome editing, conditional knock-out (cKO) mice serve as an important model for studying the function of genes. cKO mice can be produced using loxP knock-in (KI) mice in which lox $P$ sequences (34 bp) are inserted on both sides of a specific region in the target gene. These mice can be used as KO mice that do not express a gene at a desired time or under a desired condition by cross-breeding with various $\mathrm{Cre}$ Tg mice. Genome editing has been recently made easy by the use of third-generation gene scissors, the CRISPR-Cas9 system. However, very few laboratories can produce mice for genome editing. Here we present a more efficient method for producing loxP KI mice. This method involves the use of an HDR vector as the target vector and ssODN as the donor DNA in order to induce homologous recombination for producing loxP KI mice. On injecting $20 \mathrm{ng} / \mu \mathrm{L}$ of ssODN, it was observed that the target exon was deleted or loxP was inserted on only one side. However, on injecting $10 \mathrm{ng} / \mu \mathrm{L}$ of the target HDR vector, the insertion of lox $P$ was observed on both sides of the target region. In the first PCR, seven mice were identified to be $l o x P$ KI mice. The accuracy of their gene sequences was confirmed through Sanger sequencing. It is expected that the lox $P$ KI mice produced in this study will serve as an important tool for identifying the function of the target gene.

Key Words: CRISPR/Cas9 system, Conditional KO mouse, loxP, ssODN, Target HDR vector, Conventional KO mouse, Knock-in mouse, crRNA, tracrRNA

인간유전체 프로젝트(Human genome Project) 이후 빠르 게 발전한 염기서열 분석 기술을 통해 인간과 마우스의 게놈 서열이 밝혀지면서 유전자의 기능을 규명하기 위한 많은 연구들이 진행되고 있다(Li et al., 2019). 이러한 연구 에 다양한 형태의 유전자 편집 기술을 통한 유전자 과발 현(transgenic, $\mathrm{Tg}$ ), 유전자 결손(Knock-out, $\mathrm{KO})$, 유전자 삽 입(Knock-In, KI) 마우스들이 이용되고 있다(Yu and Bredley, 2001; Yan et al., 2014; Cox et al., 2015). 그 중에서도 KO 마 우스는 유전자의 기능을 규명하는데 중요한 마우스 모델 이다. 전통적인 $\mathrm{KO}$ 마우스는 표적 유전자가 발생과정에 서부터 결손 된 형태로 초기 발생에 중요한 기능을 하는 유전자를 $\mathrm{KO}$ 시키면 발생과정 중에 배아가 사망하거나
태어나자마자 바로 사망하기 때문에 유전자의 기능을 연 구하기 어려웠다. 이러한 문제를 해결하기 위해 특정 시 기나 특정 조직에서만 유전자가 결손 되도록 만든 모델 이 conditional $\mathrm{KO}$ mouse (cKO mouse)이다. $\mathrm{cKO}$ 마우스는 Cre-loxP 시스템을 이용하여 제작할 수 있으며 Cre 재조 합 효소(Cre recombinase)는 두 개의 $\operatorname{lox} P$ 부위를 인식해서 자르고 다시 DNA를 연결시킨다. 이러한 과정에서 유전 자의 결손 또는 유전자의 역위가 유도되면서 타겟 유전 자의 발현을 억제시킬 수 있다(Sauer and Henderson, 1988; Skarnes et al., 2011). cKO 마우스는 타겟 유전자 exon 부위 양끝에 $\operatorname{lox} P$ 서열을 삽입하여 만들 수 있으며 특정 시기 나 조직에서만 발현하는 다양한 $\mathrm{Cre} \mathrm{Tg}$ 마우스와 교배하

Received: May 14, 2020 / Revised: June 15, 2020 / Accepted: June 16, 2020

*Professor

${ }^{\dagger}$ Corresponding author: Sundo Jung. Department of Biomedical Laboratory Science, Shinhan University, 95, Hoam-ro, Uijeongbu-si, Gyeonggi-do 11644, Korea.

Tel: +82-31-870-3714, Fax:+82-31-870-3719, e-mail: jungsd93@shinhan.ac.kr

(C) The Korean Society for Biomedical Laboratory Sciences. All rights reserved.

(9) This is an Open Access article distributed under the terms of the Creative Commons Attribution Non-Commercial License (http://creativecommons.org/licenses/by-nc/3.0/) which permits unrestricted non-commercial use, distribution, and reproduction in any medium, provided the original work is properly cited. 
Table 1. Sequence of crRNA, tracrRNA, ssODN and PCR primer used in this study

\begin{tabular}{|c|c|}
\hline Oligo name & Sequence \\
\hline TTxx LcrRNA & 5'-TGG TGG TTA CCG GAA GCC TA GGG-3' \\
\hline TTxx RcrRNA & 5'-CTG CGG TCT CTA GAT CCT GA GGG-3' \\
\hline tracrRNA & $\begin{array}{l}\text { 5'-AAACAGCAUAGCAAGUUAAAAUAAGGCUAGUCCGUUAUCAACUUGAAAAAGUGGC } \\
\text { ACCGAGUCGGUGCU-3' }\end{array}$ \\
\hline L-ssODN & $\begin{array}{l}\text { 5'-CAGCACCTGGGGAGATGACATTTGTCTCACCTCTGGGGTGGTGGTGGTGGTTACCGGA } \\
\text { AGCCTAATAACTTCGTATAGCATACATTATACGAAGTTATGGGTTGTGGACGAGGGATAAA } \\
\text { GTCTGGGGTGGGGGACGGGGTGGTGAAGCAGGATTAAGGAGCGC-3' }\end{array}$ \\
\hline R-ssODN & $\begin{array}{l}\text { 5'-GAGGAGTACAGGTGGGAGAAGGATTTCCCTATTTATTTTTTAAGCACTGCGGTCTCTAG } \\
\text { ATCCTGAATAACTTCGTATAATGTATGCTATACGAAGTTATGGGATGTGGGTTAGTATCTGA } \\
\text { ACAGTTTAATTTGTCCCACTGGTTGAATGAGAAGCTACT-3' }\end{array}$ \\
\hline F-loxP & 5'-TGCACTGCGGGTTACAGTCC-3' \\
\hline S-loxP & 5'-AGACTTTATCCCTCGTCCACAACCC-3' \\
\hline R-loxP & 5'-CAACCAGTGGGACAAATTAAACTGTT-3' \\
\hline
\end{tabular}

면 연구자가 원하는 시기나 조직에서 타겟 유전자가 삭 제된 마우스를 얻을 수 있다(Sauer and Henderson, 1988; Skarnes et al., 2011; Ma et al., 2017).

3세대 유전자 가위인 CRISPR/Cas9 system은 작은 염 기쌍 가이드 RNA (sgRNA)와 $\mathrm{Cag}$ 9 단백질을 사용하여 $\mathrm{DNA}$ 를 부위-특이적인 방식으로 표적화하고 절단하는 방법으로 쉽고 빠르기 때문에 최근 많은 연구자들이 이 기술을 이용한 다양한 유전자 편집 마우스를 생산하고 연 구에 이용하고 있다(Cho et al., 2013; Hsu et al., 2013; Ran et al., 2013; Horii et al., 2014; Ravuex et al., 2017). 하지만 아직 개발 초기 단계로 많은 시행 착오가 발생하며 특히 target 하고자 하는 유전자의 특성으로 인해 확립된 protocol이 존재하고 있지 않아 연구자마다 다양한 방법들을 시도하 고 있는 실정이다(Chu et al., 2016). 최근에는 single strand oligodeoxynucleotide (ssODN)의 합성 기술이 발달하면서 상 동재조합(homologous recombination, HR)을 유도할 때 large fragment의 donor vector를 이용하기 보다 ssODN을 이용한 시도들도 보고되고 있다(Lanza et al., 2018; Okamoto et al., 2019). 본 연구에서는 CRISPR/Cas9 system을 이용하여 $\mathrm{cKO}$ 마우스를 제작하기 위해 중요한 target 유전자 주변 에 loxP가 삽입된 $\mathrm{KI}$ 마우스를 제작하고자 하였다. 또한 $\mathrm{HR}$ donor로 homology directed repair (HDR) donor vector와 $\mathrm{ssODN}$ 을 이용하여 loxP KI mouse 생산의 효율을 비교하 였다. $\operatorname{lox} P \mathrm{KI}$ 마우스 생산에 효과적인 방법을 제시하고, 향후 제작된 마우스를 이용하여 다양한 Cre-Tg 마우스와 교배를 통해 얻어진 $\mathrm{cKO}$ 마우스로부터 TTxx 유전자의 기능을 밝히고자 한다.
TTxx loxP Knock-In mouse 제작을 위해 미국국립생물정 보센터(NCBI)에서 $\mathrm{TTxx}$ 유전자의 염기 서열을 확인하였 으며, 유전자 결실이 유도되었을 때 전체적인 frameshift가 발생하는 exon 4 를 타겟팅 하였다. 유전자의 exon 4 양쪽 바깥쪽 intron 부위에 loxP 서열을 삽입하기 위해, Cas9 단 백질이 인식해서 자르는 target 부위를 RGEN과 MIT와 같 은 웹에서 제공하는 서열 분석 tool을 이용하였다. Exon 4 의 5 ' intron과 $3^{\prime}$ intron 부위에서 $\mathrm{TTxx}$ LcrRNA와 $\mathrm{TTxx}$ RcrRNA 서열을 선정하였으며 각각의 crRNA와 공통적인 tracrRNA는 다마콘에서 합성하였다(Fig. 1, Table 1). 상동재 조합을 유도할 donor DNA는 target $\mathrm{HDR}$ vector와 ssODN 을 이용하여 loxP KI mouse의 생산 효율을 비교하고자 하 였다. 먼저 target HDR vector를 제작하기 위해, TTxx 유전 자 exon 4의 $5^{\prime}$ intron에서 LcrRNA 부위에 loxP 서열인 5'ATA ACT TCG TAT AAT GTA TGC TAT ACG AAG TTA T -3' (34 bp)을 삽입하고 상동재조합이 일어날 수 있도록 intron 서열을 포함하여 5' HR arm (962 bp)을 선정하였다. 5' HR arm과 유사하게 3' HR arm (962 bp)도 exon 4의 3' intron에서 RcrRNA 부위에 loxP 서열인 5'- ATA ACT TCG TAT AAT GTA TGC TAT ACG AAG TTA T -3' (34 bp)을 삽 입하였다. Exon 4를 포함한 target 부위가 $2,145 \mathrm{bp}$ 인 염기 서열을 pUC57 vector의 EcoRI 제한효소 부위에 삽입되도 록 디자인 하였으며 바이오니아(Bioneer, Korea)에서 합성 하였다(Fig. 1A). 다음으로는 $\mathrm{ssODN}$ 을 HR donor로 사용하 기 위해 exon 4의 5' intron에서 LcrRNA 부위에 $\operatorname{loxP}$ 서열 인 5'- ATA ACT TCG TAT AAT GTA TGC TAT ACG AAG TTA T -3' (34 bp)를 삽입하고 $\operatorname{lox} P$ 부위 양쪽에서 상동재조 
(A)

TTxx LcrRNA: $\quad$ TTxx RcrRNA:

5' TGG TGG TTA CCG GAA GCC TA GGG 3' 5' 5TG CGG TCT CTA GAT CCT GA GGG 3'

$<w t$ allele $>$

$<$ target HDR vector>

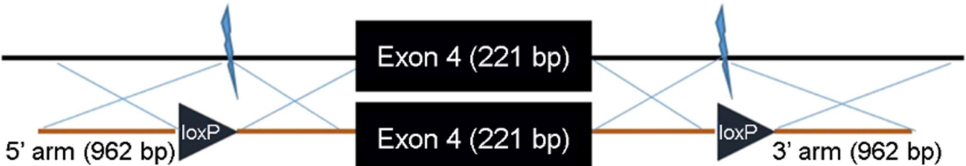

$<$ recombinant allele>

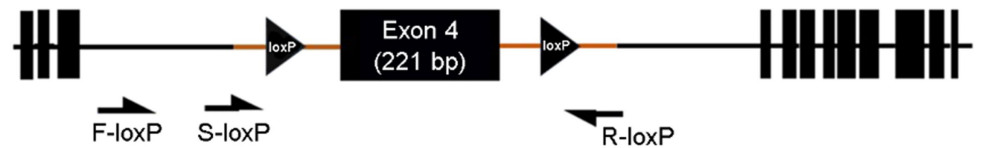

B

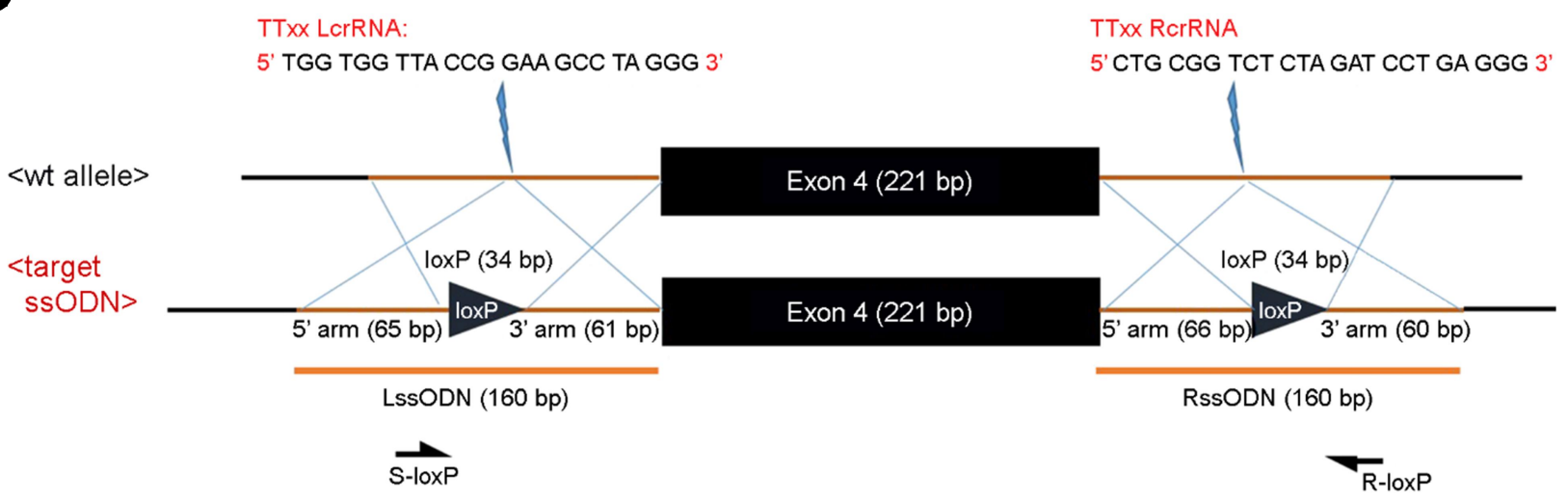

Fig. 1. Target HDR vector and ssODN designs for conditional KO mouse. Exons of TTxx gene are indicated by the black boxes and targeted exon is 4. In order to insert loxP into the outer intron region of exon 4, TTxx LcrRNA and TTxx RcrRNA selected to recognize and cut of Cas9 protein. F-loxP, S-loxP and R-loxP are PCR primer for confirming the generation and sequencing of cKO mouse. (A) HDR donor vector consists of about $1 \mathrm{~Kb}$ homologous arms containing loxP site around the Exon 4. (B) Each ssODN contains a loxP sequence (triangle) and consists of about $60 \mathrm{bp}$ homologous arms around the loxP site.

합이 일어날 수 있도록 intron 서열을 포함하여 5' HR arm (65 bp)와 3' HR arm (61 bp)을 LssODN (160 bp)로 Intergrated DNA Technologies (IDT, Coralville, IA)에서 합성하였 다. RssODN도 $\mathrm{LssODN}$ 과 마찬가지 방법으로 exon 4의 3' intron에서 RcrRNA 부위에 loxP 서열인 5'- ATA ACT TCG TAT AAT GTA TGC TAT ACG AAG TTA T -3' (34 bp)을 삽 입하고 $\operatorname{lox} P$ 부위 양쪽에서 상동재조합이 일어날 수 있 도록 intron 서열을 포함하여 5' HR arm (66 bp)와 3' HR $\operatorname{arm}(60 \mathrm{bp})$ 을 포함한 RssODN (160 bp)을 디자인하고 IDT (Coralville, IA)에서 합성하였다(Fig. 1B). 본 연구에서 진행 한 동물 실험은 고려대학교 생명공학원 계림실험동물 자 원센터에서 수행하였으며 고려대학교 실험동물 윤리위원 회의 승인을 받아 승인된 지침에 따라 윤리적 기준에 의 거하여 수행하였다(KUIACUC-2018-25).

$\operatorname{lox} P \mathrm{KI}$ 마우스 제작을 위한 microinjection은 $\mathrm{C} 57 \mathrm{BL} / 6$
암컷 mouse에 과배란을 유도한 후 수정란을 분리하고 (Ittner and Gotz, 2007) 수정란의 전핵에 준비된 crRNA, tracrRNA, Cas9 protein (NEB, USA)과 target HDR donor $\mathrm{DNA}$ 또는 $\mathrm{ssODN}$ 를 혼합하여 주입하였다. Cas9 단백질과 tracrRNA, crRNA는 기존에 발표했던 방법인 Cas9 $100 \mathrm{ng}$ $\mu \mathrm{L}, 0.6 \mathrm{pmol} / \mu \mathrm{L}$ tracrRNA, TTxx LcrRNA와 TTxx RcrRNA 는 $0.6 \mathrm{pmol} / \mu \mathrm{L}$ 를 이용하여 수정란의 전핵에 microinjection 하였다(Jung, 2019). HR donor는 가장 효율적인 농도로 알 려진 target HDR vector $10 \mathrm{ng} / \mu \mathrm{L}$ (Jung, 2019)와 각각의 ssODN $20 \mathrm{ng} / \mu \mathrm{L}$ (Raveux et al., 2017)를 사용하였다. 먼저 수정란을 이식한 후 3주 후에 태어나는 새끼 마우스의 숫자를 확인하였다. ssODN을 주입한 후 전체 131마리의 새끼가 태어났으며, target HDR vector를 주입한 경우에는 전체 241마리의 새끼를 얻을 수 있었다. ssODN과 target HDR vector를 microinjection 한 후 새끼를 얻는 과정에서 
(A)
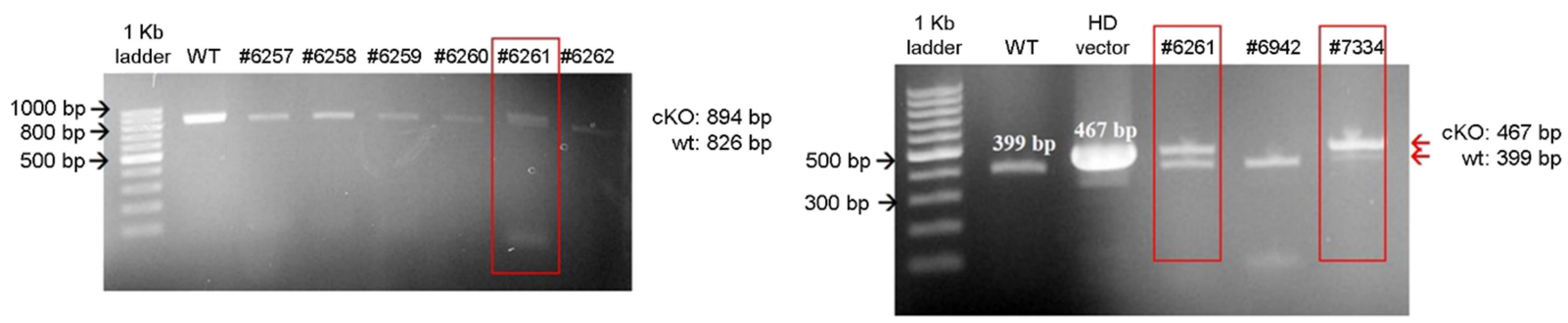

B
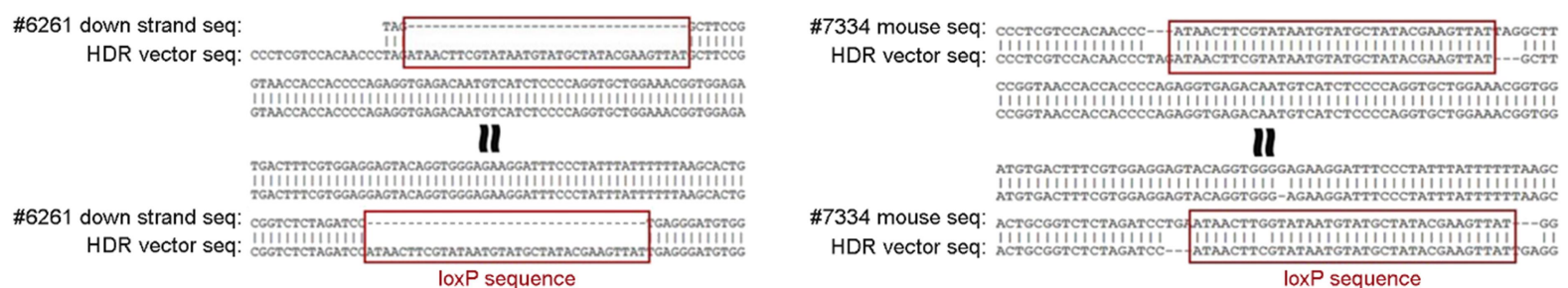

Fig. 2. Analysis of Txx cKO mouse. (A) CRISPR/Cas9-mediated cKO mice were confirmed by 1st and 2nd PCR. 1st PCR using F-loxP and $\mathrm{R}$-loxP primer set confirm insertion of loxP (894 bp) and 2nd PCR using S-, R-loxP primer set confirm precise intergration of loxP sequence for cKO mouse. (B) Through the Sanger sequencing using the second PCR products, it was confirmed that the correct sequence of loxP was inserted in \# 6261 and \# 7334 mice. As a result of alignment of the sequenced cKO mouse and the designed cKO vector, \#6261 mouse indicates $l o x P$ inserted allele and non loxP allele. As a result of alignment of the sequenced $\mathrm{cKO}$ mouse and the designed $\mathrm{cKO}$ vector, it was found that \# 7334 mice are homozygotes.

$5.2 \%$ 와 $19.1 \%$ 의 차이로 HDR vector를 주입했을 때 높은 효율을 보였다. CRISPR-Cas9 system을 통해 얻어진 새끼들 은 4주령에 꼬리의 일부를 잘라 genomic DNA를 추출한 후 $\mathrm{PCR}$ 을 통해 $\operatorname{lox} P$ 서열의 삽입 유무를 확인하였다. 먼저 1차 PCR은 F-loxP와 R-loxP primer를 이용하여 loxP 서열 삽입 여부를 확인하고자, AccuPower ${ }^{\circledR}$ HotStart PCR PreMix (Bioneer, Korea), 각 primer ( $25 \mathrm{pmol})$ 각 $1 \mu \mathrm{L}$, genomic DNA $1 \mu \mathrm{L}$ 및 $\mathrm{DW} 17 \mu \mathrm{L}$ 를 mix하여 최종 $20 \mu \mathrm{L}$ 로 $\mathrm{PCR}$ 반응을 실시했다. 반응 조건은 $95^{\circ} \mathrm{C}$ 에서 5 분간 초기 변성 후, $95^{\circ} \mathrm{C}$ 에서 30 초, $57.5^{\circ} \mathrm{C}$ 에서 30 초, $72^{\circ} \mathrm{C}$ 에서 70 초를 총 30 회 반복 수행 후 $72^{\circ} \mathrm{C}$ 로 5 분간 최종신장을 실시하 였으며, PCR 산물은 $1 \%$ agarose gel에서 $100 \mathrm{~V} \mathrm{30}$ 분 동안 전기영동 후 결과를 확인하였다. Fig. 2에서와 같이 loxP 서열 두 개가 삽입되지 않으면 $826 \mathrm{bp}$ 크기를 나타내며, 두 개의 $\operatorname{loxP}$ 가 삽입되면 PCR products의 크기가 $894 \mathrm{bp}$ 로 나타난다. 이러한 크기 변화가 관찰된 마우스는 target $\mathrm{HDR}$ vector에서 7마리가 확인되었다(Fig. 1A). 하지만 $\operatorname{ssODN}$ 을 주입한 후 태어난 7마리 마우스에서는 두 개의 $\operatorname{lox} P$ 가 삽입되었을 때 나타나는 $894 \mathrm{bp}$ 크기가 관찰되지 않았다. 7 마리 중 2 마리는 전통적인 $\mathrm{KO}$ 으로 exon 4 가 결 손 된 형태와 5마리는 크기가 $894 \mathrm{bp}$ 보다 작은 크기가 관 찰되었다(data not shown). 1차 PCR을 통해 유전자 편집이 일어난 것으로 예상되는 14 마리의 유전자 염기 서열을 확 인하기 위해, 14마리의 genomic DNA을 S-loxP와 R-loxP primer로 2 차 $\mathrm{PCR}$ 을 1차 $\mathrm{PCR}$ 과 동일한 조건으로 진행 하였다. 2차 $\mathrm{PCR}$ 을 통해 다시 한번 두 개의 $\operatorname{loxP}$ 가 삽입 된 크기를 확인하였으며(467 bp), 2차 PCR 산물은 정확한 $\operatorname{loxP}$ 염기 서열이 삽입되었음을 확인하기 위해 염기서열 분석(Bioneer, Korea)을 실시하였다. 분석 결과, Target HDR vector를 이용해서 얻은 7마리는 모두 두 개의 $\operatorname{lox} P$ 가 삽 입되었으며 정확한 $\operatorname{lox} P$ 서열을 갖는 것을 확인하였다 (Fig. 2). Target HDR vector를 주입해서 얻은 7마리 중 일부 결과만 제시하였다. 먼저 6,261 과 같이 1 차, 2 차 $\mathrm{PCR}$ 결과 에서 두 개의 band로 heterozygote alleles을 갖는 PCR 산물 은 up strand와 down strand로 구분하여 gel elution 후 염기 서열을 분석하였다. Fig. 2B에서와 같이 6,224의 up strand 
는 exon 4 바깥쪽의 양쪽에 $\operatorname{lox} P$ 서열이 삽입되어 있으며, 6,224 의 down strand는 loxP가 삽입되지 않은 wild type mouse 서열을 갖는 heterozytes 임을 확인하였다. 반면 7,334 마우스는 두 개의 allele 모두 exon 4의 바깥쪽 intron 양쪽 에 loxP 서열이 삽입된 homozytes임을 확인할 수 있었다. $\mathrm{ssODN}$ 을 주입해서 얻은 마우스 중 1 차 $\mathrm{PCR}$ 에서 다른 양 상의 PCR 산물 크기를 보여준 7마리의 2차 PCR 산물들 도 염기 서열을 분석하였다. 염기서열 분석 결과, 2 마리는 $\mathrm{KO}$ mouse로 LcrRNA와 RcrRNA 서열에서 정확하게 Cas9 단백질에 의해 잘리고 연결되면서 exon 4 가 완전히 사라 진 것을 확인하였다. 나머지 5마리는 $\operatorname{loxP}$ 가 5' 또는 3' 에서 한 개씩만 삽입되었음을 확인할 수 있었다(data not shown). 결과적으로 ssODN을 donor로 사용한 경우, 본 연 구팀에서 원하는 $\operatorname{lox} P \mathrm{KI}$ 마우스를 얻을 수 없었다. 최종 적으로 $\operatorname{lox} P \mathrm{KI}$ mouse 생산은 $0 \%$ 의 $\mathrm{ssODN}$ 과 $2.9 \%$ target HDR vector로 나타났으며, target HDR vector를 상동재조 합의 donor DNA로 사용할 때 유전자 편집 마우스 생산의 높은 효율을 보였다. Raveux et al.에 의하면 $20 \mathrm{ng} / \mu \mathrm{L}$ 의 $\mathrm{ssODN}$ 을 donor DNA로 사용한 경우 $15 \%$ 의 Knock-In 효 율을 보이며, $40 \mathrm{ng} / \mu \mathrm{L}$ 의 $\mathrm{HDR}$ plasmid를 사용한 경우에는 $12 \% \mathrm{KI}$ 과 $62 \%$ 의 indel이 유도된다고 보고하였다. 이번 연 구에서는 HDR plasmid를 사용했을 때 $100 \%$ loxP KI mouse 가 생산되었으나, 본 연구팀의 다른 연구에서는 HDR plasmid를 사용했을 때 $\operatorname{lox} P \mathrm{KI}$ allele과 $\mathrm{KO}$ allele을 갖는 hetorozytes 마우스도 낮은 빈도로 관찰되는 것으로 볼 때 crRNA의 설정 효율이거나 본 연구에서 더 많은 새끼 마 우스를 분석했다면 $\mathrm{KO}$ 마우스들도 나왔을 것으로 예상된 다. 최근 ssODN 합성 기술의 발달로 기존에 $120 \sim 200 \mathrm{bp}$ 의 $\mathrm{ssODN}$ 보다 $1,000 \sim 2,000 \mathrm{bp}$ 의 long $\mathrm{ssODN}$ 을 사용했을 때 $\mathrm{KO}$ 효율은 낮추고 $\operatorname{lox} P$ 삽입 효율이 증가되는 것을 보고하였으며, 많은 연구팀에서 다양한 크기의 ssODN을 이용한 유전자 편집에 대한 효율적인 방법들을 제시하고 있다(Codner et al., 2018; Lanza et al., 2018; Okamoto et al., 2019; Gurumurthy et al., 2019). 쉽고 빠르게 유전자 편집이 가능한 CRISPR/Cas9 system이 발달하면서 다양한 형태의 유전자 편집이 이루어지고 있으나(Fu et al., 2013; Horii et al., 2014; Chu et al., 2015; Gurumurthy et al., 2019) 편집하고자 하는 유전자 서열의 특성으로 모든 유전자에 일반적으로 동일한 조건을 적용하기는 어렵다. 본 연구팀에서도 다양 한 유전자에 대해 유전자 편집 기술을 적용해 보았지만 유전자마다 조금씩 다른 효율을 나타내었다. 따라서 유전 자 편집 마우스 생산에서 안정적인 microinjection 기술 확
보와 유전자 서열 분석 능력, crRNA 선별 능력을 갖추는 것이 중요하다고 생각된다. 안정적인 Microinjection 기술 의 경우 많은 투자와 훈련이 필요한데, 최근에는 electroporation를 이용하여 수정란의 전핵에 주입이 가능해져 (Channabasavaiah et al., 2019; Okamoto et al., 2019; Gurumurthy et al., 2019) microinjection 기술이 없다면 가장 효과적인 조건을 확립하여 electroporation을 적용하는 것도 좋은 방 법이 될 수 있다. 본 연구를 통해 target HDR vector를 이 용하여 효과적으로 $\operatorname{lox} P \mathrm{KI}$ 마우스를 제작하였으며, 향후 $\mathrm{Cre} \mathrm{Tg}$ 마우스와 교배를 통해 조건부 TTxx 유전자 결실을 유발하여 유전자의 기능을 규명하는데 높은 가치가 있을 것으로 기대된다.

\author{
Abbreviations \\ Cas9: CRISPR-associated protein 9 \\ cKO mouse: conditional KO mouse \\ CRISPR: \\ clustered regularly interspaced short palindromic repeat \\ crRNA: CRISPR RNAs \\ HDR: homology direct repair \\ HR: homologous recombination \\ KI mouse: knock-in mouse \\ KO mouse: conventional KO mouse \\ sgRNA: single strand guide RNA \\ ssODN: single strand oligo deoxynucleotide \\ tracrRNA: trans-activating crRNA
}

\section{ACKNOWLEDGEMENT}

본 논문은 2020년도 신한대학교 학술연구비 지원으로 연구되었음.

\section{CONFLICT OF INTEREST}

No potential conflict of interest relevant to this article was reported.

\section{REFERENCES}

Channabasavaiah B, Gurumurthy BC, Sato M, Nakamura A, Inui M, Kawano N, Islam AM, Ogiwara S, Takabayshi S, Matsuyama M, Nakagawa S, Miura H, Ohtsuka M. Creation of CRISPR-based germline-genome-engineered mice without ex vivo handling of zygotes by i-GONAD. Nat Prot. 2019. 
14: $2452-2482$.

Cho SW, Kim S, Kim JM, Kim JS. Targeted genome engineering in human cells with the Cas9 RNA-guided endonuclease. Nat Biotechnol. 2013. 31: 230-232.

Chu VT, Weber T, Wefers B, Wurst W, Sander S, Rajewsky K, Kuhn R. Increasing the efficiency of homology-directed repair for CRISPR-Cas9-induced precise gene editing in mammalian cells. Nat Biotechnol. 2015. 33: 543-548.

Chu VT, Weber T, Graf R, Sommermann T, Petsch K, Sack U, Volchkov P, Rajewsky K, Kühn R. Efficient generation of Rosa26 knock-in mice using CRISPR/Cas9 in C57BL/6 zygotes. BMC Biotechnol. 2016. 16: 86-97.

Codner FG, Mianne J, Caulder A, Loeffler J, Fell R, King R, Allan A, Mackenzie M, Pike JF, McCabe VC, et al. Application of long single-stranded DNA donors in genome editing: generation and validation of mouse mutants. BMC Biol. 2018. 16: 70 .

Cox DBT, Platt JR, Zhang F. Therapeutic Genome Editing: Prospects and Challenges. Nat Med. 2015. 21: 121-131.

Fu Y, Foden JA, Khayter C, Maeder ML, Reyon D, Joung JK, Sander JD. High-frequency off-target mutagenesis induced by CRISPR-Cas nucleases in human cells. Nat Biotechnol. 2013. 31: 822-826.

Gurumurthy BC, O'Brien RA, Quadros MR, Adams J, Alcaide P, Ayabe S, Ballard J, Batra KS, Beauchamp MC, Becker AK, et al. Reproducibility of CRISPR-Cas9 methods for generation of conditional mouse alleles: a multi-center evaluation. Genome Biol. 2019. 20: 171-184.

Horii T, Arai Y, Yamazaki M, Morita S, Kimura M, Itoh M, Abe Y, Hatada I. Validation of microinjection methods for generating knockout mice by CRISPR/Cas-mediated genome engineering. Sci Rep. 2014. 4: 4513-4518.

Hsu PD, Scott DA, Weinstein JA, Ran FA, Konermann S, Agarwala V, Li Y, Fine EJ, Wu X, Shalem O, Cradick TJ, Marraffini LA, Bao G, Zhang, F. DNA targeting specificity of RNA-guided Cas9 nucleases. Nat Biotechnol. 2013. 31: 827 -832 .

Ittner LM, Gotz J. Pronuclear injection for the production of transgenic mice. Nat Protoc. 2007. 2: 1206-1215.

Jung S. Efficient generation of human IgG1 light kappa constant region knock-in mouse by CRISPR/Cas9 system. Biomedical Science Letters. 2019. 25: 372-380.

Lanza GD, Gaspero A, Lorenzo I, Liao L, Zheng P, Wang Y, Deng Y, Cheng C, Zhang C, Seavitt RJ, DeMayo FJ, Xu J, Dickinson
ME, Beaudet AL, Heaney JD. Comparative analysis of singlestranded DNA donors to generate conditional null mouse alleles. BMC Biology. 2018. 16: 69.

Li Q, Qin Z, Wang Q, Xu T, Yang Y, He Z. Applications of genome editing technology in animal disease modeling and gene therapy. Computational and Structural Biotechnology Journal. 2019. 17: 689-698.

Ma X, Chen C, Veevers J, Zhou X, Ross RS, Feng W, Chen J. CRISPR/Cas9-mediated gene manipulation to create singleamino-acid-substituted and foxed mice with a cloning-free method. Sci Rep. 2017. 7: 42244-42252.

Okamoto S, Amnaishi Y, Maki I, Enoki T, Mineno J. Highly efficient genome editing for single-base substitutions using optimized ssODNs with Cas9-RNPs. Sci Rep. 2019. 9: 4811 $-4821$.

Raveux A, Vandormael-Pournin S, Cohen-Tannoudji M. Optimization of the production of knock-in alleles by CRISPR/Cas 9 microinjection into the mouse zygote. Sci Rep. 2017. 7: 42661 -42670 .

Ran FA, Hsu PD, Lin CY, Gootenberg JS, Konermann S, Trevino AE, Scott DA, Inoue A, Matoba S, Zhang Y, Zhang F. Double nicking by RNA-guided CRISPR Cas9 for enhanced genome editing specificity. Cell. 2013. 145: 1380-1389.

Sauer B, Henderson N. Site-specific DNA recombination in mammalian cells by the Cre recombinase of bacteriophage P1. Proc Nactl Acad Sci. 1988. 85: 5166-5170.

Skarnes WC, Rosen B, West AP, Koutsourakis M, Bushell W, Iyer V, Mujica AO, Thomas M, Harrow J, Cox T, Jackson D, Severin J, Biggs P, Fu J, Nefedov M, de Jong PJ, Stewart AF, Bradley A. A conditional knockout resource for the genomewide study of mouse gene function. Nature. 2011. 474: 337 -342 .

Yan H, Wang H, Jaenisch R. Generating genetically modified mice using CRISPR/Cas-mediated genome engineering. Nat Protoc. 2014. 9: 1956-1968.

Yu Y, Bredley A. Engineering chromosomal rearrangements in mice. Nat Rev Genet. 2001. 2: 780-790.

https://doi.org/10.15616/BSL.2020.26.2.114

Cite this article as: Jung S. Efficient Production of loxP Knock-in Mouse using CRISPR/Cas9 System. Biomedical Science Letters. 2020. 26: 114-119. 